\title{
From ethnomusicologist to composer. Sándor Veress and the Moldavian Collection
}

\author{
IOANA BAALBAKI, Lecturer PhD \\ University of Arts Târgu Mureș \\ ROMANIA*
}

\begin{abstract}
As a student of Zoltán Kodály and Béla Bartók, but also a close collaborator of László Lajtha at the Hungarian Ethnographic Museum in Budapest, and later of Béla Bartók at Folk Department of the Hungarian Academy of Science, Sándor Veress followed the path of his masters regarding the relation with folklore music. In 1930, he undertook an expedition in Moldavia, Romania, to collect music from the Csángó population, a small Hungarian speaking community, of catholic faith, living in the east of the Carpathian Mountains. In the seven villages he has visited, he collected, with the help of the phonograph, 138 folk songs on 57 wax cylinders, taking in the same time around 60 pictures and documenting the whole expedition in a journal. Following this journey, during the 30's, Sándor Veress not only transcribed and analyzed the entire material, but also selected some of the melodies and used them as theme for his own choir arrangements and chamber music compositions.
\end{abstract}

Keywords: Sándor Veress, Csángó music, Moldavian Collection, Paul Sacher Collection.

\section{Introduction}

The present study is the result of the research carried out within the grant offered by the Paul Sacher Foundation in Basel, Switzerland, which involved the study of the Veress Fund. The central theme of the research project was the collection of folk songs from Moldavia and its use in the early works of the composer. We structured the research into three sections, each becoming a chapter of the present study. The first step of the research consisted in following the artistic evolution of Sándor Veress and the key moments that determined his accomplishment as a pianist, composer and ethnomusicologist, a step that was materialized by going through the bibliographical materials regarding his life and work. A second stage of the research focused on the collection of songs from Moldavia, from collection to publication, in this respect browsing the valuable material in the composer's handwriting preserved in Paul Sacher Foundation. The third step of the research consisted in analyzing the manuscripts of the composer's creation in order to identify their relationship with the Moldavian collection. The research was not limited

\footnotetext{
*ioanabaalbaki@gmail.com
} 
only to the completed pieces, which were also published, but we also considered numerous works or sketches that for one reason or another were not completed.

\section{Sándor Veress from pianist to ethnomusicologist and composer}

Born on February 1, 1907 in Kolozsvár (today Cluj-Napoca, Romania), into a family of Hungarian intellectuals who supported his artistic inclination, Sándor Veress first followed the path of music with his mother Mária VeressMéhely, described as a good pianist and singer (Traub, 1986, p. 23). Due to the outbreak of World War I, Sándor moved with his family to Budapest where his father, Endre Veress, a renowned historian, was appointed to a position in the Ministry of Foreign Affairs. Thus, he attended secondary education courses in the Hungarian capital, and at the same time he also studied piano, first in private with Professor Maria Demény, and from the age of 16 he was admitted to "Fr. Liszt" Music Academy, joining the class of Emanuel Hegyi. In 1929 he obtained a degree in Theory and Composition attending the classes taught by composer Zoltán Kodály, and in 1932 a degree in piano, studying with Béla Bartók, thus having the chance to be modelled by two of the most important composers, educators and ethnomusicologists of the $20^{\text {th }}$ century.

Ever since his student years, beginning in 1929, he worked as a volunteer in the musical folklore section of the Hungarian Ethnographic Museum, being an assistant to the ethnomusicologist and composer László Lajtha, together with whom he started collecting, transcribing and systematizing folk music. Thus, he undertook expeditions to the regions inhabited by Hungarians and carried out various activities regarding collecting, transcribing songs from wax cylinders and cataloguing materials (Laki, 2008, p. 189). To this period is dated his first individual expedition, to the Moldavian Csángós, which we will discuss in detail in the following chapter.

In 1934 he received the assistant position to Béla Bartók in the Folklore Department of the Hungarian Academy of Sciences, where he worked until 1949. Other expeditions would follow: to the Rábaköz area in western Hungary, visited in 1934 and 1935; to Dudar (Veszprém reg.) and Vág villages (Sopron reg.) in 1937 and subsequently to Transylvania, which had been reverted to Hungary, in the area of the Transylvanian Plain, in 1943. Three songs from Brașov area are recorded as well, namely from Satu Lung (hu: Hosszúfalu) (Berlász, 1982, p. 140), without noting the circumstances or the year in which this collection took place.

An important moment in the ethnomusicological activity of Sándor Veress was the participation, between 1937-1938, along Béla Bartók, in the Pátria project, consisting in the selection and recording of Hungarian peasants from all Hungarian dialectal areas. As part of the project, two peasant women from the village of Trunc in Moldavia were brought to Budapest, where they 
sang the Hegyen földön [Over Hills and Valleys] song and the Oláhul Merinka ballad (Laki, 2008, p. 199).

The ethnomusicological activity of the 1930s was doubled by an intense compositional activity, which included valuable works for solo piano, chamber ensembles and various choral pieces, published and available for the first time. These include Kis zongoradarab nép és gyermekdalok 115 Short Pieces for Piano] (1935), 15 Gyermekkar [15 Children's Choruses] (1936), Erdély kantáta [Transylvanian Cantata] (1936), Die Wunderschalmei (ballet, 1937), 6 Csárdás for piano (1938), Kis szvit [Little Suite] (1938), Dudari nóták [Songs from Dudar] (1939), Guzsalyasban [In the Spinning Room] (1939), etc. In the study dedicated to the composer Sándor Veress, Ede Terényi captured the stylistic features of the youth works from 1931-1950, that the composer followed in the footsteps of Kodály and Bartók, tributary to the Hungarian folk melos (Terényi, 1982, p. 59).

The 1940s, marked by World War II, represented a period of great achievements and changes in the composer's life. In 1943, as a result of Zoltán Kodály's retirement, Sándor Veress was designated head of the composition department of the "Fr. Liszt" National Music Academy in Budapest, among its students being György Ligeti and György Kurtág. In September 1948, as a recognized and appreciated ethnomusicologist, he participated as official delegate to the Congress of the International Society of Ethnomusicology, organized in Basel, Switzerland. Despite the numerous achievements on a professional level, the establishment of the totalitarian regime in Hungary determined Sándor Veress to emigrate. Following an invitation, he had received from Sweden to attend the premiere of his ballet Térszili Katicza, composed in Rome in 1942, he left his homeland on February 6, 1949, leaving for Stockholm, without having the chance to return ever again. On the compositional plane, he wrote many valuable pieces, such as Symphony No. 1 (1940), Sancti Augustini Psalmus contra partem Donati for bass, choir and large orchestra (1943-1944), Canti Ceremissi for mezzo-soprano and piano (1945), Threnos, in memoriam Béla Bartók for large orchestra (1945), Fingerlarks for piano (1946), Vier Transsylvanische Tänze für Streichorchester (1943/1949), some of them being published and performed, others unfortunately only in manuscript version.

After a short time spent in Rome, Veress settled in Bern, Switzerland, where from 1950 on was invited to hold university courses in ethnomusicology, and later also in music theory and composition.

The break from the mother country led to the emergence in the composer's creation of a new stage of artistic expression. Along with the emigration, the composer renounced almost entirely to the neoclassical style of folkloric essence, finding a new musical language through the composition techniques of the Second Viennese School. Thus, began a period of 
dodecaphonic and then serialist compositions which includes pieces such as: Hommage à Paul Klee for two pianos and string orchestra (1951), Concert for Piano, Strings and Percussion (1952), Minneapolitana Symphony for large orchestra (1952), Trio for Violin, Viola and Cello (1954) and Laudatio musicae (1958).

The intense didactic activity that would take him to both North America and Australia was not to be followed by an equally sustained compositional activity. The best-known works of the 1960s include Ode all'Europa (1962), Elegie for baritone, harp and string orchestra (1964), Concert for Klarinet and Orchestra (1981-1982), Trio for Baryton, Viola and Cello (1985) and Orbis Tonorum (1986).

Folklore was permanently present in the composer's life and, after the fifth decade of the twentieth century, not just as a source of inspiration but as a teaching subject. Thus, in his conferences or courses held in Bern and at other host institutions, he would regularly address this topic from the perspective of both the pedagogue and the ethnomusicologist or composer. His folklorefocused articles include Folk music in music and general education and Der homo ornans in Musik'.

\section{The Moldavian collection, from recording to publication}

In 1930, at the age of only 23, Sándor Veress embarked on an ethnomusicological and ethnographic expedition to the remote region of Moldavia, Romania, first passing through Bucharest, where he made contact with Constantin Brăiloiu in order to obtain access permits to the area (Veress, 1989, p. 17). In Moldavia he intended to research and collect the folklore of the Csángós, a Catholic minority, speaking an archaic Hungarian dialect, who were located east of the Eastern Carpathians, in the vicinity of the rivers Bistrita and Siret. The choice of the region seems to be at least bizarre, in the political and social context of the time, but as justified and logical as possible in the context of the gatherings and researches of Hungarian ethnomusicologists. The region had been researched in 1929 by Pál Péter Domokos, but not by Zoltán Kodály, who had visited Bucovina (in the north of Moldavia), nor by Béla Bartók, who had set out to reach the area, but the outbreak of World War I had hampered his plans.

"Loaded with paper, 60 cylinders of wax for the phonograph and a knapsack full of many other necessities, on July 11, I boarded the train and reached the first destination of my research: Szabófalva" (Veress, 1989, p. 17). Thus, between July 11 - August 11, 1930, he visited seven villages inhabited by the Csangos: the village of Săbăoani (Hu: Szabófalva), located near the

\footnotetext{
${ }^{1}$ Republished in Traub, A. (Ed.) (1998). Sándor Veress. Aufsätze, Vorträge, Briefe. Bern: Wolke Verlag Hofheim.
} 
Roman municipality, Cleja (Hu: Klézse), Fărăoani (Hu: Forrófalva), Valea Seacă (Hu: Bogdánfalva), Somușca (Hu: Somoska), Galbeni (Hu: Trunk) and Chetriș (Hu: Ketris) ${ }^{2}$ south of Bacău.

The results of his field research are valuable, as he collected on 57 wax cylinders over 130 pieces, mainly solo vocal songs, along with a few instrumental pieces. Regarding the exact number of works, the bibliography offers several variants. In the introductory word to the Moldavia collection, Sándor Veress mentions the collection of 135 songs (Veress, 1989, p. 17) indicating with a single number - 135 - the four instrumental pieces collected from Valea Seacă. Péter Laki (2008, p. 193) and Melinda Berlász (1982, p. 139) mention 137 pieces, the two researchers probably referring only to the vocal songs and calculating the overall songs and the three songs sung in two variants - Hungarian and Romanian. Going through the collection we identified 134 vocal songs and 4 instrumental songs all recorded under the figure 135 . Of the 134 vocal songs, 3 are transcribed with text both in the dialect of the Csángós and in the Romanian language: no. 48, no. 107 and no. 134. This results in a total of 138 individual songs. In the 32 days he spent among the Csángós (July 11-August 11, 1930), Sándor Veress kept a journal in which he noted his travel experiences and took over 60 photographs of the villages visited, as well as of housing and peasants dressed in folk clothing.

Returning to Budapest, Sándor Veress transcribed the collected material, following the principles of transcription and systematization of the Hungarian school of ethnomusicology, but the material was not to be soon published. In the following years only a small part of the collected pieces was published in different collections of Hungarian folk tunes ${ }^{3}$.

The characteristics and value of the collection are comprised in two articles: Népzenei gyüjtés a moldvai csángók között [Folks gatherings among Moldavian Csángós] (Ethnographia journal, 1931. 2. 133-142.1.) and Székely népballadák változatai Moldvában [Variations of Szekler ballads in Moldavia] (Néprajzi Értesítő journal, 19-161.2.). In addition, Sándor Veress wrote a series of short notes, unpublished, but preserved in manuscript form in the Veress Fund at the Paul Sacher Foundation in Basel, Switzerland (Laki, 2008, p. 190).

In 1989, almost six decades after the collection of songs, the entire collection of songs, together with the journal and photographs of Sándor Veress, were published in Budapest in the series Magyar népköltési gyüjtemény [Hungarian folk music]. The volume edited by researchers Melinda Berlász and Olga Szalay contains a thorough ethnomusicological study conducted by the two researchers. We emphasize the presence of two prefaces, first in

\footnotetext{
${ }^{2}$ See the map in Veress, 1989, p. 41.

${ }^{3}$ Péter Laki pointed out exactly the extent of diffusion of the collected pieces (2008, pp. 191193).
} 
Hungarian - a wide one, and a second one in German - a shorter version, written by Sándor Veress, in which he described the historical and social context of the Csángós and the auspices under which the expedition took place.

In the Veress collection at the Paul Sacher Foundation is preserved the entire musical material transcribed by Sándor Veress. Researching the handwritten folders, we identified three stages of notation / transcription, which gives us an image of the steps taken by the researcher in transcribing and understanding the musical material. A first, schematic stage is found in the folk songbook that accompanied the composer in all his expeditions of the 1930s and 1940s. The book contains melodic lines, possibly taken during the recording of the songs, sometimes with rhythmic durations. A second stage, realized after his return to Budapest, consists in the accurate notation of the main melodic line and rhythm, as well as the poetic text. A third stage, found only in some of the transcribed pieces, consists in the recording of the melodic differences in each stanza, as well as the precise notation of the melodicrhythmic ornaments.

We emphasize the accuracy with which the composer transcribed the folk songs, not only at the musical level but also at the linguistic level. The Csángós speak an archaic Hungarian dialect enriched with Romanian linguistic elements. Sándor Veress captured this in his transcripts, introducing explanatory notes for each foreign term in the Hungarian language, notes that can be found both in the manuscript and in the published version of the material. Since the Csángó dialect involved certain phonemes different from the classical Hungarian language, the researcher devised a phonetic system for their transcription, which can be found in the manuscript collection on page 1 .

As for the contents of the collection, Sándor Veress transcribed and numbered the materials in the order in which they were recorded. Each transcribed piece contains the number of the cylinder on which it was registered (in Roman numerals and small letters from $a$ to $d$ ) and the cataloguing number in the collection of the Hungarian Folklore Archive (MH from 2442/a-to 2497). Since the materials in the Veress collection were not organized according to Bartók's principles, being placed in the order in which they were archived, we believe that the systematization of the collection, as we find it in the published version, was carried out by the two researchers: Melinda Berlász and Olga Szalay.

\section{Csángó music in Veress compositions}

For the Hungarian composers trained under the auspices of the school of Zoltán Kodály and Béla Bartók, folklore was the main source of inspiration, collecting and capitalizing on it both scientifically and artistically being the duty of the young generation. At the same time, the Hungarian cultural and educational movement, built on Kodály's principles, supported the 
development of the national cultural life through the establishment of choral ensembles. For these ensembles, the young composers wrote dedicated works, which were immediately published in national anthologies spread throughout the country.

In this context, it is not surprising that the young Veress followed in the composition the path clearly outlined by the Hungarian masters, Kodály and Bartók, but also by Lázsló Lajtha, whom he mentioned in this regard: "At first I followed Kodály and Bartók in the treatment of the musical material of folk origin, however quickly and not in the least due to Lajtha's influence I started to experiment with the folk musical material, experiments in which I tried to transform / decompose the motifs of some songs and not only to assemble any melodic line with any accompaniment, but rather to compose an entire work based on the motivic material" (Traub, 1986, p. 225).

With the exception of two materials, whose date of composition is not noted, all the compositions that are the subject of our research were composed in the 1930s. Although the composer himself characterized the period of the 1930s as the "sonatina years" (Traub, 1986, p. 36), a rich body of works of this period is represented by the choral genre. Sándor Veress selected a series of songs from the Moldavia collection that he chose to adapt for various choral structures: children's choruses for two voices, mixed choruses for three voices, male choruses for two, three and four voices, mixed choruses for five voices, two male choruses, etc.

A special feature of Veress' choral creation is the way he organized these pieces. The vast majority of the works are choral suites, with several parts, each part representing a piece built on a folk song. Veress composed suites based solely on pieces from the Moldavia collection, such as the Hét csángó gyermekdal Moldvából [Seven Csángó children songs from Moldavia], or Guzsalyasban (Négy moldvai csángó népdal) [In the Spinning Room (Four Csángó songs)], but he also composed mixed suites in which he introduced songs from the Moldavia collection, together with Hungarian songs from other regions, collected by important Hungarian ethnomusicologists such as Zoltán Kodaly and Béla Bartók. The second category includes the collections Erdély kantáta [Transylvanian cantata] and Kárpátokon innen és túl [On both sides of the Carpathians].

In the instrumental genre we have identified three materials so far, a miniature for piano published in the collection 15 Kis zongoradarab magyar nép és gyermekdalok [15 little pieces for piano], a dance piece for clarinet in $B^{b}$, violin, timpani and bass drum, entitled Borica-tánc (Moldvából) [Călușar (from Moldavia)] unpublished but found in manuscript at Paul Sacher Foundation, and the first 5 measures for a piano trio available also at Paul Sacher Foundation. 
As we examined both the bibliography and the manuscripts, we identified a series of works based on the Moldavia collection, whose manuscripts did not survive. These are Két moldvai csángó magyar népdal [Two CsángóHungarian folk songs from Moldavia] and 15 Kis zongoradarab magyar nép és gyermekdalok [15 short pieces for piano] which are marked accordingly in Table 3. A particular case is the collection Öt népdal énekre moldvai csángó gyüjtéséböl [Five Csángó folk songs from Moldavia] identified in the list of works published by Melinda Berlász (1982, p. 162), which however is not present either as manuscript or material published by Paul Sacher Foundation.

In order to have an overview of the creation of Sándor Veress regarding the Moldavia collection, we devised table 3, in which, together with the name of the collection, we included their parts in the version in which they were found in the manuscript as well as in the published one. The reader will be surprised by the diversity of the ways of notation of the parts: with Arabic or Latin numerals, with agogic indications or bearing representative titles. All these versions repeat identically the type of notation used by the composer, and in the case of published materials, by the publisher as well. We chose to introduce the number of the piece from the Moldavia collection both next to each column - manuscript, or publication, respectively - so that the reader may easily notice the similarities and differences between the two versions. Table 4 starts from the Moldavia collection and its representation in Veress' creation, in order to perform a statistical analysis on the folklore material used.

In the following we will briefly discuss all the materials based on the Moldavia collection found in the manuscript at Paul Sacher Foundation and which, if published, present differences between the manuscript and the publication. In the present study does not intend to carry out a musical analysis, however this type of research may be the subject of a future study.

By browsing the autograph manuscripts, we were able to identify a certain consistency in the notation. The vast majority of manuscripts studied are noted with a black ink pen (possibly dark blue ink). In case of structural changes, information (year, part number, page) the composer made red pencil markings.

7 csángó gyermekdal Moldvából [Seven Csángó children songs from Moldovia] is a collection of children's songs structured in two sections, of 4 and 3 choruses, respectively. The manuscript of the piece reveals that Veress worked in two stages on the material. In 1931 he composed a collection entitled 5 csángó gyermekdal Moldvából [Five Csángó children songs from Moldovia] which was not published. Five years later, in 1936, he resumed the collection, removed two pieces (no. 2 and no. 3) and composed another four. One of them, Virágének [Flower Song] will be part of the first segment of the collection, and the next 3 pieces will become the second segment of the 
collection. Being a collection of children's songs, the composer named each piece with a suggestive title (see Table 1).

\begin{tabular}{|c|c|}
\hline 1931 Variant & 1936 Variant \\
\hline 1. Táncnóta [Dance & I. Táncnóta [Dance \\
\hline Song] & Song] \\
\hline 2. A doktor legény [The & II. Virágének \\
\hline Young Doctor] & [Flower Song] \\
\hline 3. Kuk-nóta [The & III. Duda-nóta \\
\hline Cuckoo Song] & [Bagpipe Tune] \\
\hline 4. Duda-nóta [Bagpipe & IV. Táncnóta \\
\hline Tune] & [Dance Song] \\
\hline 5. Táncnóta [Dance & --- \\
\hline Song] & I. Beköszöntő \\
\hline & [Greeting] \\
\hline & II.. Cigány-nóta \\
\hline & [Gipsy song] \\
\hline & III. Táncnóta \\
\hline & [Dance Song] \\
\hline
\end{tabular}

Tabel 17 (5) csángó gyermekdal Moldvából collection in two variants

All 9 pieces, of which only 7 are published, are arrangements of some pieces from the Moldavia collection; table 3 indicates the corresponding song in the collection next to each piece.

Két csángó-magyar népdal [Two Csángó-Hungarian songs] is a cycle of two pieces for four male voices ( 2 tenors and 2 basses) composed in $1931^{4}$ based on two songs from the Moldavia collection. The work is in manuscript form in the Paul Sacher Collection and has not been published until now. Moreover, it is important to draw attention to the fact that the manuscript is not written neither in the composer's handwriting nor by his mother. ${ }^{5}$ The work is not mentioned in the list drawn up by Melinda Berlász, which causes us to doubt, to some extent, that it is part of the composer's creation.

In 1932 Sándor Veress composes a chamber work for clarinet in $B^{b}$, violin, timpani and bass drum entitled Borica-tánc (Moldvából) [Călușar (from Moldavia)]. The work kept in manuscript form in the Paul Sacher Foundation Archive has not been published until now. The chamber piece represents a processing of the song published under number 134 in the Moldavia Collection (Veress, 1989, pp. 277-278), to which Veress paid special attention. Collected from Kata Mihaly from the village of Valea Seacă, the song was sung in both

\footnotetext{
${ }^{4}$ Mentioned on the first page of the manuscript.

${ }^{5}$ Mária Veress-Méhely, the composer's mother, transcribed numerous compositions by Sándor Veress, some of them found in the Paul Sacher Foundation Archive.
} 
Hungarian and Romanian, being transcribed in both languages and supplemented with an explanatory note referring to a song of traditional Romanian dancers published by Franz Schultzer in 1781 in Geschichte des Transalpinische Daciens (Veress, 1989, p. 278). The Romanian version is none other than the famous song Ana Lugojana used by Filaret Barbu in his homonymous work in 1950. The small instrumental piece (50 measures) contains indications of tempo and agogic, musical dynamics and techniques. The fact that the paper does not have traces of corrections and the piece is completed with a double bar-line makes us consider the manuscript as a final form of creation.

Öt csángó gyermekdal Moldvából [Five Csángó children songs from Moldovia] is a three-part children's chorus cycle composed by Sándor Veress in 1932 but never published in this form. Three of the songs in the cycle were published in the Négy csángó gyermekdal Moldvából cycle [Four csángó children songs from Moldavia], which is why we will discuss the content of the two cycles in comparison. Both collections contain choral arrangements of the pieces collected in Moldavia (see table 3), table 2 presenting the contents of the two collections. The composer brought some changes to the song Macskácskának [To the Kitten], found in the second collection under the title Kis macskának [Little Kitten], both at the level of the title and implicitly of the text and also regarding the metric aspect. At first the song was noted in alternative measure structures of $3 / 8,2 / 8$, but afterwards it was transcribed in $2 / 8,3 / 8$ metre.

The two pieces kept in the manuscript variant, Libidori dombon [Libidori Hill] and Fekete tyúk [Black Hen], are completed works, containing besides the melodic material, indications of agogic and dynamics and including the poetic text; in the case of the first piece all four stanzas are noted. We draw attention to this aspect because most of the studied manuscripts did not contain any indications of agogic or dynamics, the text being rarely noted, and generally only partially.

\begin{tabular}{|l|l|}
\hline $\begin{array}{l}\text { Öt csángó gyermekdal } \\
\text { Moldvából }\end{array}$ & $\begin{array}{l}\text { Négy csángó gyermekdal } \\
\text { Moldvából }\end{array}$ \\
\hline 1. Csúfolódó [Mocking Song] & 1. Csúfolódó [Mocking Song] \\
2. Macskácskának [To the Kitten] & 2. Bogár-lakadalom [Beetle \\
3. Libidori dombon [Libidori & Wedding] \\
Hill] & 3. Kis macskának [Little Kitten] \\
4. Fekete tyúk [Black Hen] & 4. Táncnóta [Dancing Song] \\
$\begin{array}{l}\text { 5. Bogár-lakadalom [Beetle } \\
\text { Wedding] }\end{array}$ & \\
\hline
\end{tabular}

Tabel 2 Common songs in Öt \& Négy csángó gyermekdal Moldvából 
In 1939 Sándor Veress composed the cycle of pieces entitled Guzsalyasban [In the Spinning Room] for two-part mixed choir. The manuscript at Paul Sacher Foundation does not contain a title and is not dated, some pieces not being completed, in the sense that they do not have a double bar at the end, they do not contain text or agogic and dynamics indications, these aspects determining us to consider that the preserved manuscript represents a stage in the composition and completion of the cycle.

On the level of the cycle structure, together with the 4 pieces in the published version, the manuscript contains a fifth piece from the Moldavia collection, song no. 49, Eme hègyen foly è påtåk [There is a stream running on this mountain]. The song which the composer also processed in 1932 in the collection Négy csángó gyermekdal Moldvából [Four Csángó children songs from Moldavia], is presented in a new version. In the first collection, the composer chose to process the musical material for three-part children's choir, exposing the four melodic lines of the folk melody in voice 1, while voices 2 and 3 support the harmonic accompaniment; later, in the reprise of line 1 he inserts a three-voice imitative polyphony, based on the thematic material of the first two melodic lines. In the version found in the Guzsalyasban [In the Spinning Room] manuscript, the composer transposes the melody, initially built on a minor pentatonic scale on $G$, to a minor third below. The theme, exposed by the soprano, is counterpointed freely by the tenor voice, until the 4 melodic lines are exhausted, and then accompanied by a melodic pendulum of a descending major second $(D-C)$ to which is superimposed a pedal on $A$. Thus, in the central part of the song, the sound material is amplified to three voices, before it returns to the original version. The song is not completed, in the last 15 measures of the manuscript the composer returning twice with completions, aspects that can be noticed due to the different writing utensils that overlap the original manuscript. In the first phase the manuscript was drafted with a black pen, and subsequently the composer returned using a red coloured pencil and a graphical pencil. The last four measures, left incomplete, as well as the lack of the double bar-line makes us to consider the piece as uncompleted.

Csúfolódó [Mocking song] is a choral work, for two-voice double choir, unpublished and undated, based on song no. 111 from the Moldavia collection. We find the song no. 111 processed in a different way, for 3-voice children's choir in the collection Négy csángó gyermekdal Moldvából [Four Csángó children songs from Moldavia] and in the unpublished collection Öt csángó gyermekdal Moldvából [Five Csángó children songs from Moldavia]. 


\section{Conclusions}

Of the 134 vocal songs from the Moldavia collection, we were able to identify 34 songs that formed the basis of Veress' compositions, predominant being the choral genre in different hypostases. Only 3 pieces became the theme of some instrumental works (or only sketches), namely no. 14, no. 49 and no. 134.

Although the vast majority of the pieces, to be exact 27 pieces, were used in choral or instrumental arrangements only once, we also noticed the preference songs, which the composer adapted several times. In this second category is included the piece no. 49, with the variant $\mathrm{C}$ of the text, Macskácskának négy lába [Cat's Four Legs]. This was adapted first as a children's choir piece for three voices in Négy csángó gyermekdal Moldvából, afterwards as a piano miniature in 15 Kis zongoradarab magyar nép és gyermekdalok and again as a mixed choir piece for two voices in Guzsalyasban, unfortunately this version not being published.

Following his emigration to Switzerland, Sándor Veress abandoned almost entirely the choral creation, with few exceptions, and the adaptation of Hungarian folk songs as well.

\begin{tabular}{|c|c|c|c|c|c|}
\hline Year & $\begin{array}{l}\text { Colection } \\
\text { name/Musical piece }\end{array}$ & $\begin{array}{l}\text { Manuscript } \\
\text { (Paul Sacher } \\
\text { Stiftung) }\end{array}$ & $\begin{array}{l}\text { No. in } \\
\text { Moldova } \\
\text { Collection }\end{array}$ & $\begin{array}{l}\text { Published } \\
\text { version }\end{array}$ & $\begin{array}{l}\text { No. in } \\
\text { Moldova } \\
\text { Collection }\end{array}$ \\
\hline f.a. & $\begin{array}{l}\text { Csúfolódó [Mocking } \\
\text { song] } \\
2 \text { female choirs }\end{array}$ & Allegro moderato & 111 & unpublished & \\
\hline f.a. & Piano trio & Sketches, $5 \mathrm{~mm}$. & 14 & & \\
\hline $\begin{array}{l}1931 / \\
1936\end{array}$ & $\begin{array}{l}7 \text { csángó } \\
\text { gyermekdal } \\
\text { Moldvából } \\
\text { [Seven csángó } \\
\text { children songs from } \\
\text { Moldavia] } \\
2 \text { voices children's } \\
\text { choir }\end{array}$ & $\begin{array}{l}\text { 1. (I) Táncnóta } \\
\text { [Dance song] } \\
\text { 2. (-) A doktor } \\
\text { legény [The Young } \\
\text { Doctor] } \\
\text { 3. (-) Kuk-nóta [The } \\
\text { Cuckoo Song] } \\
\text { 4. (III) Duda-nóta } \\
\text { [The Bagpipe Tune] } \\
\text { 5. (II) Virágének } \\
\text { [Flower Song] } \\
\text { 6. (IV) Táncnóta } \\
\text { [Dance Song] } \\
\text {--- } \\
\text { 7. (I) Beköszöntő } \\
\text { [Greeting] } \\
\text { 8. (II) Cigany-nóta } \\
\text { [Gipsy Song } \\
\text { 9. (III) Táncnóta } \\
\text { [Dance Song] }\end{array}$ & $\begin{array}{l}106 \\
42 \\
118 \\
108 \\
21 \\
\text { Libidori } \\
24 \\
--- \\
72 \\
69 \\
114\end{array}$ & $\begin{array}{l}\text { I. Táncnóta } \\
\text { [Dance Song] } \\
\text { II. Virágének } \\
\text { [Flower Song] } \\
\text { III. Duda-nóta } \\
\text { [The Bagpipe } \\
\text { Tune] } \\
\text { IV. Táncnóta } \\
\text { [Dance Song] } \\
\text {--- } \\
\text { I. Beköszöntő } \\
\text { [Greeting] } \\
\text { II. Cigány-nóta } \\
\text { [Gipsy Song] } \\
\text { III. Táncnóta } \\
\text { [Dance Song] }\end{array}$ & $\begin{array}{l}106 \\
21 \\
108 \\
24 \\
--- \\
72 \\
69 \\
114\end{array}$ \\
\hline
\end{tabular}

${ }^{6}$ A list of compositions by Sándor Veress till 1982 can be found in Berlász, M. \& Demény, J. \& Terényi, E. 1982, p. 156-173. For an updated list see www.veress.net 


\begin{tabular}{|c|c|c|c|c|c|}
\hline 1931 & $\begin{array}{l}\text { Két csángó-magyar } \\
\text { népdal } \\
\text { [Two csángó- } \\
\text { hungarian songs] } \\
4 \text { voices men choir }\end{array}$ & $\begin{array}{l}\text { Allegro } \\
\text { Trio }\end{array}$ & $\begin{array}{l}104 \\
42\end{array}$ & unpublished & - \\
\hline 1932 I & $\begin{array}{l}\text { Borica-tánc } \\
\text { (Moldvából) } \\
\text { [Călușar (From } \\
\text { Moldavia)] } \\
\text { (For clarinet in B, } \\
\text { violin, timpani and } \\
\text { drum) }\end{array}$ & $\begin{array}{l}\text { Borica-tánc } \\
\text { (Moldvából) } \\
\text { [Căluşar (From } \\
\text { Moldavia)] }\end{array}$ & 134 & unpublished & - \\
\hline $\begin{array}{l}1932 . \\
X\end{array}$ & $\begin{array}{l}\text { Öt csángó } \\
\text { gyermekdal } \\
\text { Moldvából } \\
\text { [Five csángó } \\
\text { children songs from } \\
\text { Moldavia] } \\
3 \text { voices children's } \\
\text { choir }\end{array}$ & $\begin{array}{l}\text { 1. Csúfolódó } \\
\text { [Mocking Song] } \\
\text { 2. Macskácskának... } \\
\text { [To the Kitten] } \\
\text { 3. Libidori } \\
\text { dombon... [Libidori } \\
\text { Hill] } \\
\text { 4. Fekete tyúk } \\
\text { [Black Hen] } \\
\text { 5. Bogár-lakadalom } \\
\text { [Beetle Wedding] }\end{array}$ & $\begin{array}{l}111 \\
49 \mathrm{C} \\
104 \\
121 \\
115\end{array}$ & see below & - \\
\hline $1932 ?$ & $\begin{array}{l}\text { Négy csángó } \\
\text { gyermekdal } \\
\text { Moldvából } \\
\text { [Four csángó } \\
\text { children songs from } \\
\text { Moldavia] } \\
3 \text { voices children's } \\
\text { choir }\end{array}$ & $\begin{array}{l}\text { 1. Csúfolódó } \\
\text { [Mocking Song] } \\
\text { 2. Bogár-lakadalom } \\
\text { [Beetle Wedding] } \\
\text { 3. Kis macskának } \\
\text { [Little Kitten] } \\
\text { 4. Tancnóta [Dance } \\
\text { Song] }\end{array}$ & $\begin{array}{l}111 \\
115 \\
49 \mathrm{C} \\
105\end{array}$ & $\begin{array}{l}\text { I. Csúfolódó } \\
\text { [Mocking Song] } \\
\text { II. Bogár- } \\
\text { lakadalom } \\
\text { [Beetle Wedding] } \\
\text { III. Kis } \\
\text { macskának... } \\
\text { [Little Kitten] } \\
\text { IV. Tancnóta } \\
\text { [Dance Song] }\end{array}$ & $\begin{array}{l}111 \\
115 \\
49 \mathrm{C} \\
105\end{array}$ \\
\hline $\begin{array}{l}1933 \\
\text { II }\end{array}$ & $\begin{array}{l}\text { Népdal-szvit } \\
\text { [Folk-songs suite] } \\
\text { Choir }\end{array}$ & $\begin{array}{l}\text { I. } \\
\text { II. } \\
\text { III. } \\
\text { IV. }\end{array}$ & $\begin{array}{l}28 \\
22 \\
21 \\
92 \\
\end{array}$ & $\begin{array}{l}\text { I. } \\
\text { II. } \\
\text { III. } \\
\text { IV. } \\
\end{array}$ & $\begin{array}{l}28 \\
22 \\
21 \\
92 \\
\end{array}$ \\
\hline 1934 & $\begin{array}{l}\text { Két moldvai csángó } \\
\text { magyar népdal } \\
\text { [Two csángó- } \\
\text { hungarian folk-songs } \\
\text { from Moldavia] in } \\
14 \text { Magyar népdal } \\
\text { [14 Hungarian folk- } \\
\text { songs] } \\
2 \text { voices men choir }\end{array}$ & missing & & $\begin{array}{l}\text { 6. (Fúdd el jó } \\
\text { szél, fúdd el) } \\
\text { [Blow away, } \\
\text { good wind, blow } \\
\text { away] } \\
\text { 7. (Piros, piros } \\
\text { szélfü) } \\
\text { [Red, red } \\
\text { carnation] }\end{array}$ & $\begin{array}{l}8 \\
21\end{array}$ \\
\hline 1935 & $\begin{array}{l}\text { Erdély kantáta } \\
\text { [Transylvanian } \\
\text { cantata] } \\
5 \text { voices mixt choir }\end{array}$ & $\begin{array}{l}\text { III. } \\
\text { IV. }\end{array}$ & $\begin{array}{l}12 \\
61\end{array}$ & $\begin{array}{l}\text { III. } \\
\text { IV. }\end{array}$ & $\begin{array}{l}12 \\
61\end{array}$ \\
\hline 1935 & $\begin{array}{l}15 \text { Kis } \\
\text { zongoradarab } \\
\text { magyar nép és } \\
\text { gyermekdalok } \\
{[15 \text { short pieces for }} \\
\text { piano] }\end{array}$ & Missing & & $\begin{array}{l}14 . \\
\text { Macskácskának } \\
\text { [To the Kitten] }\end{array}$ & $49 \mathrm{C}$ \\
\hline
\end{tabular}




\begin{tabular}{|c|c|c|c|c|c|}
\hline $\begin{array}{l}1936 \\
\text { VII }\end{array}$ & $\begin{array}{l}\text { Két virágének } \\
\text { [Two flower songs] } \\
3 \text { voices female or } \\
\text { men choir }\end{array}$ & $\begin{array}{l}1 . \\
2\end{array}$ & $\begin{array}{l}56 \\
104\end{array}$ & $\begin{array}{l}\text { I. } \\
\text { II. }\end{array}$ & $\begin{array}{l}56 \\
104\end{array}$ \\
\hline 1936 & $\begin{array}{l}\text { Kárpátokon innen } \\
\text { és túl } \\
\text { [On both sides of the } \\
\text { Carpathians] } \\
3 \text { voices mixt choir }\end{array}$ & 2. & 15 & II. & 15 \\
\hline 1936 & $\begin{array}{l}\text { Öt népdal énekre a } \\
\text { moldvai csángó } \\
\text { gyüjtéséből }{ }^{7} \\
{[5 \text { csángó folk-songs }} \\
\text { from Moldavia] } \\
\text { Choir }\end{array}$ & Missing & & $\begin{array}{l}\text { 1. Török búza } \\
\text { [Turkish Wheat] } \\
\text { 2. Járj ki lábam } \\
\text { [Dance, Feet, } \\
\text { Step Out Now] } \\
\text { 3. Anyám, anyám } \\
\text { [Mother, Mother] } \\
\text { 4. Rengedez a } \\
\text { nádszál [Shake } \\
\text { Reeds] } \\
\text { 5. A pünkösdi } \\
\text { rózsa [Peony] }\end{array}$ & $\begin{array}{l}53 \\
71 \mathrm{~A} / \mathrm{B} \\
54 ? \\
18 \\
3 ?\end{array}$ \\
\hline 1939 & $\begin{array}{l}\text { Guzsalyasban } \\
\text { [In the Spinning } \\
\text { Room] } \\
2 \text { voices mixt choir }\end{array}$ & $\begin{array}{l}1 . \\
2 . \\
3 . \\
4 . \\
5 .\end{array}$ & $\begin{array}{l}7 \\
32 \\
51 \\
49 \\
37\end{array}$ & $\begin{array}{l}\text { I. } \\
\text { II. } \\
\text { III. } \\
\text { IV. }\end{array}$ & $\begin{array}{l}51 \\
7 \\
32 \\
37\end{array}$ \\
\hline
\end{tabular}

Tabel 3 List of composition by Sándor Veress related to Moldavian Collection

\begin{tabular}{|c|c|c|}
\hline $\begin{array}{l}\text { Number in } \\
\text { Moldavian } \\
\text { Collection }\end{array}$ & $\begin{array}{l}\text { Title/first line in Moldavian } \\
\text { collection }^{8}\end{array}$ & $\begin{array}{l}\text { Name of the collection/piece by Sándor } \\
\text { Veress }\end{array}$ \\
\hline 3 & $\begin{array}{l}\text { E pünkösti rózsa } \\
\text { [Peony] }\end{array}$ & $\begin{array}{l}\text { Öt népdal énekre a moldvai csángó } \\
\text { gyüjtéséböl? }\end{array}$ \\
\hline 7 & $\begin{array}{l}\text { Szegény legény kucorgása } \\
\text { [The Poor Lad's Huddled Up] }\end{array}$ & Guzsalyasban \\
\hline 8 & $\begin{array}{l}\text { Fudd el, jó sziél, fudd el } \\
\text { [Blow Away, Good Wind, Blow } \\
\text { Away] }\end{array}$ & Két moldvai csángó magyar népdal \\
\hline 12 & $\begin{array}{l}\text { Jöjj meg, Duna, jöjj meg } \\
\text { [Come, Danube, Come] }\end{array}$ & Erdély kantáta \\
\hline 14 & $\begin{array}{l}\text { Sirathatod mágád } \\
\text { [You Can Mourn] }\end{array}$ & Sketches for Piano trio \\
\hline 15 & $\begin{array}{l}\text { Elment è madàrkå } \\
\text { [The Little Bird Has Gone] }\end{array}$ & Kárpátokon innen és túl \\
\hline 18 & $\begin{array}{l}\text { Réngedez a nádszál } \\
\text { [Shake Reeds] }\end{array}$ & $\begin{array}{l}\text { Öt népdal énekre a moldvai csángó } \\
\text { gyüjtesból }\end{array}$ \\
\hline
\end{tabular}

${ }^{7}$ Mentioned in Berlász, M. \& Demény, J. \& Terényi, E. (1982, p. 162), but unfound in Paul Sacher Foundation Collection.

${ }^{8}$ The title/first line of the song is given in Csángó dialect, as found in the Moldavian Collection. 


\begin{tabular}{|c|c|c|}
\hline \multirow[t]{3}{*}{21} & \multirow{3}{*}{$\begin{array}{l}\text { Piros, piros székfü } \\
\text { [Red, Red Carnation] }\end{array}$} & 7 csángó gyermekdal Moldvából \\
\hline & & Népdal-szvit \\
\hline & & Két moldvai csángó magyar népdal \\
\hline 22 & $\begin{array}{l}\text { Csütökön estve } \\
\text { [On Thursday Evening] }\end{array}$ & Népdal-szvit \\
\hline 24 & $\begin{array}{l}\text { Éjen azt álmodtam } \\
\text { [I Dreamed that Night] }\end{array}$ & 7 csángó gyermekdal Moldvából \\
\hline 28 & $\begin{array}{l}\text { Jó estiét, jó estiét } \\
\text { [Good Evening, Good Evening] }\end{array}$ & Népdal-szvit \\
\hline 32 & $\begin{array}{l}\text { Mënyecske, mënyecske } \\
\text { [Young Woman, Young Woman] }\end{array}$ & Guzsalyasban \\
\hline 37 & $\begin{array}{l}\text { Tamàs Gyurka jideki } \\
\text { [Gyurka Tamàs Out Here] }\end{array}$ & Guzsalyasban \\
\hline \multirow[t]{2}{*}{42} & \multirow{2}{*}{$\begin{array}{l}\text { Ién vóltam egy doftor legyiény } \\
\text { [I Was a Young Doctor] }\end{array}$} & 7 csángó gyermekdal Moldvából \\
\hline & & Két csángó-magyar népdal \\
\hline \multirow[t]{4}{*}{49} & \multirow{4}{*}{$\begin{array}{l}\text { Eme hègyen foly è påtåk } \\
\text { [There is a Stream Running on this } \\
\text { Mountain] }\end{array}$} & Öt csángó gyermekdal Moldvából \\
\hline & & Négy csángó gyermekdal Moldvából \\
\hline & & $\begin{array}{l}15 \text { Kis zongoradarab magyar nép-és } \\
\text { gyermekdalok }\end{array}$ \\
\hline & & Guzsalyasban \\
\hline 51 & $\begin{array}{l}\text { Szegány legény kucorgása } \\
\text { [The Poor Lad's Huddled Up] }\end{array}$ & Guzsalyasban \\
\hline 53 & $\begin{array}{l}\text { Török búza, iédesz málé } \\
\text { [Turkish Wheat, Sweet Malt] }\end{array}$ & $\begin{array}{l}\begin{array}{l}\text { Öt népdal énekre a moldvai csángó } \\
\text { gyǘjtéséböl }\end{array} \\
\end{array}$ \\
\hline 54 & $\begin{array}{l}\text { Anyám, anyám, édes anyám } \\
\text { [Mother, Mother, Sweet Mother] }\end{array}$ & $\begin{array}{l}\text { Öt népdal énekre a moldvai csángó } \\
\text { gyuújtéséböl }\end{array}$ \\
\hline 56 & $\begin{array}{l}\text { Hègyen, } \\
\text { füödön járogatunk vala } \\
\text { [Over Hills and Valleys] }\end{array}$ & Két virágénék \\
\hline 61 & Ki szeretet útján [Out of Love] & Erdély kantáta \\
\hline 69 & $\begin{array}{l}\text { Ien esz, ien esz, csak úd iélek } \\
\text { [Yeah, Yeah, I Just Live] }\end{array}$ & 7 csángó gyermekdal Moldvából \\
\hline 71 & $\begin{array}{l}\text { Járj ki, lábam, járj ki most } \\
\text { [Dance, Feet, Step Out Now] }\end{array}$ & $\begin{array}{l}\text { Öt népdal énekre a moldvai csángó } \\
\text { gyuújtéséböl }\end{array}$ \\
\hline 72 & $\begin{array}{l}\text { lénekeljünk, iénekeljünk } \\
\text { [Sing, Sing] }\end{array}$ & 7 csángó gyermekdal Moldvából \\
\hline 92 & $\begin{array}{l}\text { Hidegségen, ződ erdőbe születtem } \\
\text { [I Was Born in the Cold, in the } \\
\text { Forest] }\end{array}$ & Népdal-szvit \\
\hline \multirow[t]{3}{*}{104} & \multirow{3}{*}{$\begin{array}{l}\text { Zöd pántlika } \\
\text { [A Green Ribbon] }\end{array}$} & Két csángó-magyar népdal \\
\hline & & Öt csángó gyermekdal Moldvából \\
\hline & & Két virágénék \\
\hline 105 & $\begin{array}{l}\text { Haj, anyám, haj, anyám [Oh, My } \\
\text { Mom, oh, My Mom] }\end{array}$ & Négy csángó gyermekdal Moldvából \\
\hline 106 & $\begin{array}{l}\text { Hidló viégién } \\
\text { [At the End of the Bridge] }\end{array}$ & 7 csángó gyermekdal Moldvából \\
\hline 108 & $\begin{array}{l}\text { Iérik a szülö, Hajlik az ága } \\
\text { [The Grapes Ripen, the Branch } \\
\text { Bends] }\end{array}$ & 7 csángó gyermekdal Moldvából \\
\hline \multirow[t]{3}{*}{111} & \multirow{3}{*}{$\begin{array}{l}\text { Sa te fejed akkora } \\
\text { [You Are so Big] }\end{array}$} & Csúfolódó \\
\hline & & Öt csángó gyermekdal Moldvából \\
\hline & & Negy csángó gyermekdal \\
\hline
\end{tabular}




\begin{tabular}{|l|l|l|}
\hline 114 & $\begin{array}{l}\text { Tennap jártam zabaratni } \\
\text { [Yesterday I Went Crazy] }\end{array}$ & 7 csángó gyermekdal Moldvából \\
\hline 115 & $\begin{array}{l}\text { Sziép aszszony ée kenderivel } \\
\text { [Beautiful Woman with Hemp] }\end{array}$ & Öt csángó gyermekdal Moldvából \\
\cline { 2 - 3 } & $\begin{array}{l}\text { Négy csángó gyermekdal Moldvából } \\
\text { [I went to school in Pest] }\end{array}$ & 7 csángó gyermekdal Moldvából \\
\hline 118 & $\begin{array}{l}\text { Feteke tyuk, iromba } \\
\text { [Black Hen] }\end{array}$ & Öt csángó gyermekdal Moldvából \\
\hline 134 & $\begin{array}{l}\text { Most van kedvem holnap nem lész } \\
{[\text { I Feel Like You Won't Do it }} \\
\text { Tomorrow] }\end{array}$ & Borica-tánc \\
\hline
\end{tabular}

Tabel 4 Distribution of Moldavian Collection songs in Sándor Veress compositions

(Translated from Romanian by Dora Barta)

\section{References}

Berlász, M. \& Demény, J. \& Terényi, E. (1982). Veress Sándor. Budapest: Zenemükiadó.

Berlász, M. (1982). Veress Sándor - a népzenekutató [Sándor Veress as Ethnomusicologist]. In Berlász, M. \& Demény, J. \& Terényi, E. Veress Sándor (pp. 136-149). Budapest: Zenemúkiadó.

Berlász, M. (2007). Editor's Foreword I. In Veress, S. Choral Works I (pp. XIXXXII). Budapest: Editio Musica.

Berlász, M. (2010). Editor's Foreword II. In Veress, S. Choral Works II (pp. XXVXVIII). Budapest: Editio Musica.

Kerékfy, M. (2018). Kantate aus Volkslieder. Die Transsilvanische Kantate von Sándor Veress. In Obert, S. (Ed.) \& Zimmermann, H. (Ed.). RE-SET Rückgrieffe und Fortschreibungen in der Musik seit 1900 (pp. 208-215). Basel: Paul Sacher Stiftung, Edition Schott.

Laki, P. (2008). Sándor Veress als Ethnomusikologe. Die Moldau-Sammlung. In Lanz, D. (Ed.) \& Gerhard, A. (Ed.). Sándor Veress. Komponist - Lehrer - Forscher (pp. 189-203). Kassel: Bärenreiter Verlag.

Lanz, D. (Ed.) \& Gerhard, A. (Ed.) (2008). Sándor Veress. Komponist - Lehrer Forscher. Kassel: Bärenreiter Verlag.

Obert, S. (Ed.) \& Zimmermann, H. (Ed.) (2018). RE-SET Rückgrieffe und Fortschreibungen in der Musik seit 1900. Basel: Paul Sacher Stiftung, Edition Schott.

Terényi, E. (1982). Veress Sándor alkotóperiódusai [Sándor Veress stilistic periods]. In Berlász, Me. \& Demény, J. \& Terényi, E. Veress Sándor (pp. 58-136). Budapest: Zenemükiadó. 
Traub, A. (Ed.) (1986). Sándor Veress: Festschrift zum 80. Geburtstag. Berlin: Verlag K. Hasselhoff.

Traub, A. (1986). Sándor Veress, Lebensweg - Schaffensweg. In Traub, A. (Ed.). Sándor Veress: Festschrift zum 80. Geburtstag (pp. 225-257). Berlin: Verlag K. Hasselhoff.

Traub, A. (Ed.) (1998). Sándor Veress. Aufsätze, Vorträge, Briefe. Bern: Wolke Verlag Hofheim.

Veress, S. (1989). Moldvai gyüjtés [Moldavian folksongs]. Budapest: Múzsák Kiadó.

Veress, S. (1998). Der Homo ornans in der Musik. In Traub, Andreas (Ed.), Sándor Veress. Aufsätze, Vorträge, Briefe (pp. 103-123). Bern: Wolke Verlag Hofheim.

Veress, S. (2007). Choral Works I. Budapest: Editio Musica.

Veress, S. (2010). Choral Works II. Budapest: Editio Musica.

Ziegler, S. (1986). Einige Bemerkungen zur Transsylvanischen Kantate von Sándor Veress. In Traub, A. (Ed.). Sándor Veress: Festschrift zum 80. Geburtstag (pp. 225250). Berlin: Verlag K. Hasselhoff. 